\title{
Cooperative Anions Binding with Nitrophenyl Thiourea Derivative
}

\author{
Nam Joong Jeon, Hyoung Min Yeo, and Kỵe Chun Nam* \\ Department of Chemistr, and Institute of Basic Science, Chonnam National Chwersin, Guangju 500-757, Korea \\ "E-mail: kcnamóchomamackr \\ Received December 13, 2007
}

Key Words : Chromogenic receptor. Cooperative binding, Binding constant, UV-titration. Urea derivative

Development of bifunctional receptors of cation and anion guest is the exiting topic of coordination chemistry due to the fact that a large number of biological processes involve molecular recognition of cation and anion species simultaneously: Most of the known synthetic receptors capture a particular anion without undergoing interaction with the counter cation. Recently, emerging field of topical interest in supramolecular chemistry is ion-pair recognition. in which a host simultaneously binds both cationic and anionic guests. ${ }^{1.2}$ Details of these receptors. which combine. for example. crown ethers ${ }^{3}$ and calixarenes ${ }^{4}$ for cation complexation. with Lewis acid centers. ${ }^{5}$ pyrroles. ${ }^{6}$ amides ${ }^{7}$ or urea groups ${ }^{8, \bar{y}}$ for anion recognition. have been reported.

A variety of receptors containing urea subunits have been designed and tested for anion recognition and a lot of those urea chemosensors ${ }^{10}$ have been constructed based on nitropheny'l group as a signal unit. ${ }^{11}$ Optical properties of the chromogenic nitrophenyl fragment may be altered from the receptor-anion interaction, thus providing colorimetric ${ }^{12}$ and spectral sensing of the recognition event. Indeed, it has been shown that even simple chromophores. containing hydrogen-bonding donor groups. can operate as efficient colorimetric sensors for the naked-eye ${ }^{13}$ detection of anions.

For the development of efficient bifunctional receptor. a new nitrophenyl thiourea derivative 1 was synthesized and its binding properties were investigated by UV-vis spectroscopy. ${ }^{1} \mathrm{H}$ NMR and color changes. Ligand 1 showed a significant anion binding enhancement in the presence of sodium and also it could be utilized as a naked ere chemosensor owing to the noticeable color change in the presence of various anions.

\section{Results and Discussion}

Ligand 1 was synthesized from the reaction of 4'-aminobenzo-15-crown-5 ether and 4-nitrophenyl isothiocyanate in $74 \%$ yield. The ${ }^{1} \mathrm{H}$ NMR spectrum of ligand 1 showed two singlets at $\delta 8.50$ and $8.45 \mathrm{ppm}$ for two N-H protons. a pair of doublets at $\delta 8.15$ and 7.79 for four nirophenyl protons. a multiplets at $\delta 6.95 \mathrm{ppm}$ for three aromatic protons. and three broad multiplets at $\delta 4.07,3.79$ and $3.63 \mathrm{ppm}$ for the sixteen methylene protons in $\mathrm{CD}_{3} \mathrm{CN}$. A same procedure was applied for the synthesis of ligand $\mathbf{2}$ with 4-nitrophenyl isocyanate in high yield.

The UV-vis experiments were carried out in an acetonitrile solution. A receptor solution $\left(1 \times 10^{-4} \mathrm{M}\right)$ was treated with the representative anions such as tetrabutylammonium (TBA) fluoride. chloride bromide iodide dilydrogen phosphate. hydrogen sulfate. acetate and benzoate. When compound 1 forms a complex with acetate. the absorption peak at $340 \mathrm{~nm}$ disappears and a new peak appears at 390 num with a redshifted by a $\Delta \lambda_{\max }$ of $20 \mathrm{~nm}$. A clear isobestic point was observed as shown in Figure 1, indicating that neutral ligand 1 formed an anionic species with acetate ion. When acetate titration was conducted in the presence of 1 equivalent of $\mathrm{Na}^{-}$, a similar change was observed with the slight increase of absorption band at $390 \mathrm{~nm}$. When ligand 1 was treated with iodide ions. only a slight increase of $370 \mathrm{~nm}$ absorption band was observed. But. when iodide titration was conducted in the presence of 1 equivalent of $\mathrm{Na}^{+}$. more drastic increase of absorption band at $370 \mathrm{~nm}$ was noticed as shown in (d) Figure 1. Stability constants (Table 1) were calculated from the UV-vis titration results using ENZFITTER ${ }^{1+}$ for
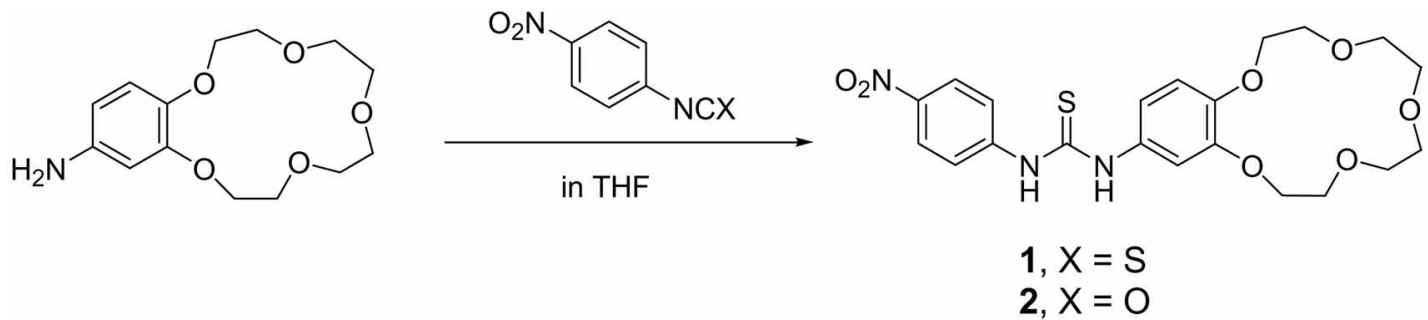

Scheme 1. Synthesis of benzo-15-crown-urea 1 and 2. 

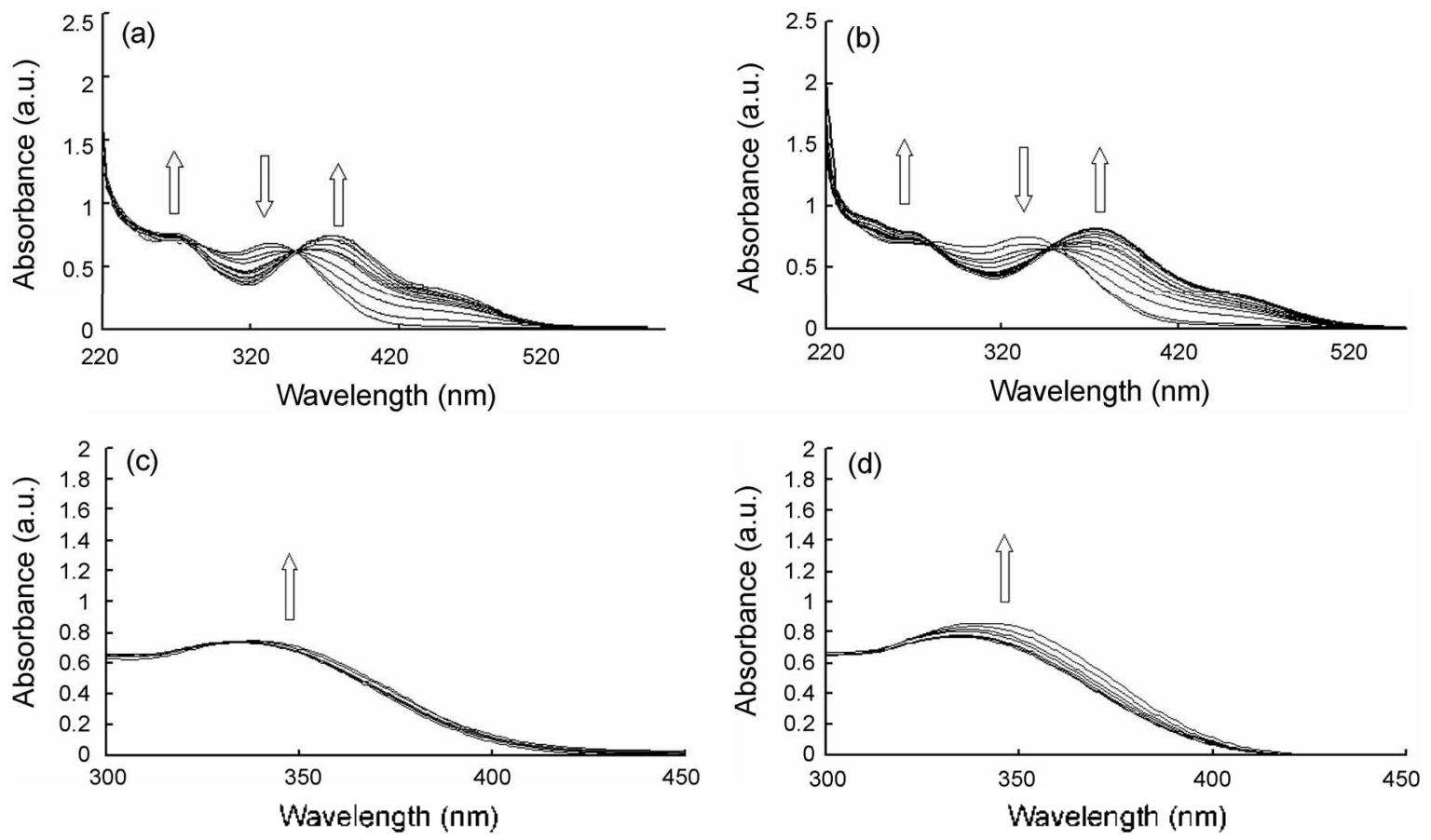

Figure 1. Family of spectra taken in the course of the titration of $\mathrm{CH}_{3} \mathrm{CN}$ solution $1.0 \times 10^{-4}$ in receptor $1,1+\mathrm{Na}^{+}$with a standard solution of acetate: (a) acetate titration only. (from $0 \mathrm{eq}$ to $5 \mathrm{eq}$ ) (b) acetate titration in the presence of $\mathrm{Na}^{+}$. (from 0 eq to 5 eq) (c) iodide titration only. (from 0 eq to $100 \mathrm{eq}$ ) (d) iodide titration in the presence of $\mathrm{Na}^{-}$. (trom 0 eq to $100 \mathrm{eq}$ )

Table 1. Association constant $K_{\sigma}\left[\mathrm{M}^{-1}\right]$ for the receptor 1 and $1+\mathrm{Na}^{+}$with various anions in $\mathrm{CH}_{3} \mathrm{CN}$

\begin{tabular}{lrlr}
\hline Anions & $K_{\sigma} / \mathrm{M}^{-1}$ & Antions & $K_{a} / \mathrm{M}^{-1}$ \\
\hline $\mathrm{CH}_{3} \mathrm{CO}_{2}^{-}$ & 10590 & $\mathrm{Cl}^{-}$ & 1286 \\
$\mathrm{CH}_{3} \mathrm{CO}_{2}^{-}\left(+\mathrm{Na}^{+}\right)$ & 13181 & $\mathrm{Cl}^{-}\left(+\mathrm{Na}^{-}\right)$ & 1368 \\
$\mathrm{BT}^{-}$ & 317 & $\mathrm{HSO}_{+}^{-}$ & 185 \\
$\mathrm{BT}^{-}\left(+\mathrm{Na}^{-}\right)$ & 518 & $\mathrm{HSO}_{+}^{-}\left(+\mathrm{Na}^{+}\right)$ & 428 \\
$\mathrm{I}^{-}$ & 146 & & \\
$\mathrm{I}^{-}\left(+\mathrm{Na}^{+}\right)$ & 280 & & \\
\hline
\end{tabular}

complexation with acetate. chloride, bronide. iodide and hỵdrogen sulfate in order to investigate binding enhancement in the presence of sodium ions. A significant increase in the strength of anion binding is observed when sodium ions are bound simultaneously. Acetate binding strength increase 1.2 fold. chloride 1.1 fold. bromide 1.6 fold. iodide 2 fold and hydrogen sulfate 2.3 fold in the presence of sodium ions. This positive cooperative binding of the anions in the presence of sodium ions could be attributed to electrostatic effects of the complexed sodium ion. Anion binds in weak positive dipoles of urea group. lodide and hydrogen sulfate binding were enlanced more than that of acetate and chloride, indicating that the relatively weak anions such as iodide and hydrogen sulfate could be influenced more effectively through electrostatic pulling of sodium ions toward ligand urea site.

A color change could be observed easily by mixing the ligand and anion as shown in Figure 2. A receptor solution was simply treated with various anions such as $\mathrm{F}^{-} . \mathrm{Cl}^{-}$. $\mathrm{Br}^{-}$. $\mathrm{I}^{-}, \mathrm{H}_{2} \mathrm{PO}_{4}^{-}, \mathrm{HSO}_{4}^{-}, \mathrm{CH}_{2} \mathrm{COO}^{-}$and $\mathrm{C}_{6} \mathrm{H}_{5} \mathrm{COO}^{-}$. Noticeable color changes were observed when ligand 1 was treated with
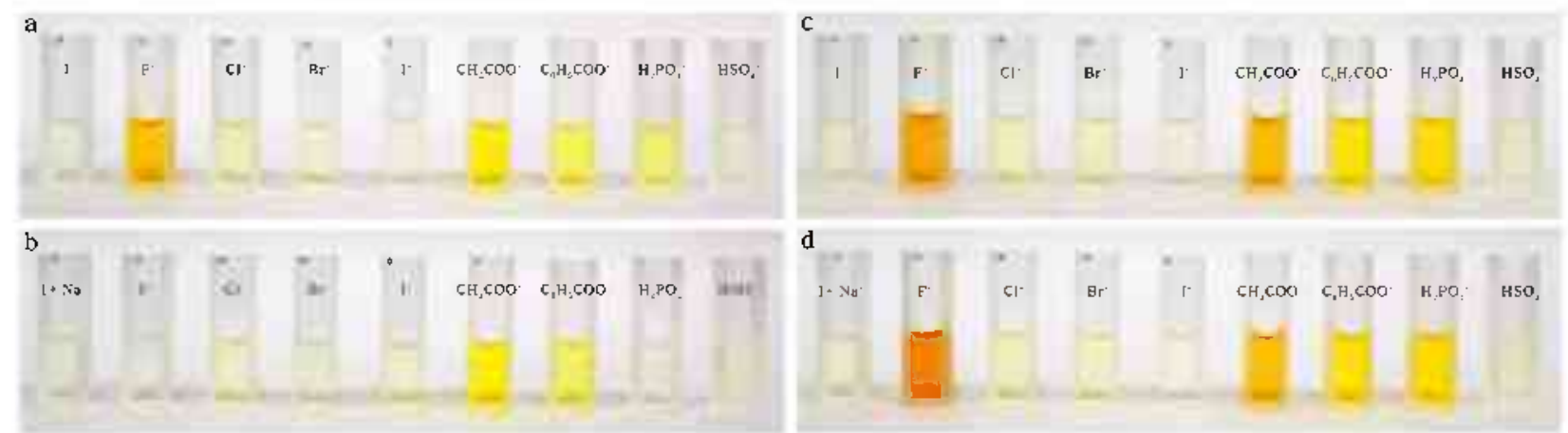

Figure 2. Color changes receptor $1\left(2 \times 10^{-3} \mathrm{M}\right)$ on addition of various anions (as a tetrabutylammonium salt) to a $\mathrm{CH}_{3} \mathrm{CN}$ solution. (a) addition of $l$ equivalent of anions. (b) addition $l$ equivalent of anions in the presence of $l$ equivalent sodium tetraphenylborate. (c) addition of 10 equivalents of anions. (d) addition of 10 equivalents of anions in the presence of 1 equivalent sodium tetraphenylborate. 


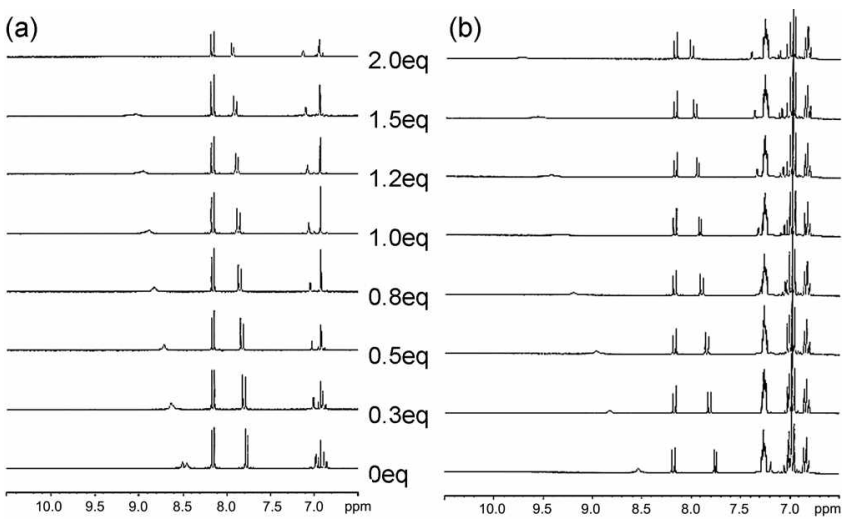

Figure 3. ${ }^{~} \mathrm{H}$ NMR spectra of ligand 1 with TBAI a) ligand 1 only, b) ligand $\mathbf{1}+\mathrm{Na}^{+}$in $\mathrm{CD}_{3} \mathrm{CN}$

the anions. A colorless ligand solution became to yellow with acetate and yellow color become weak with benzoate and dilydrogen phosphate. But when fluoride was added. yellow color was deepened. When sodium ions were added in a ligand solution with anions. a yellow color continued in the case of acetate solution. but when the yellow color was disappeared in fluoride and dilydrogen phosphate solution. Obviously fluoride left urea site and formed an ion pair with the sodium which coordinated in crown site. When the excess fluoride ions were added. the color was remained even in the presence of I equivalent of sodium ion. It could be a nice example of the negative effect of cooperative anion binding with sodium ions. A similar observation was noticed with dilhydrogen phosphate.

To look into the detail characteristics. 'H NMR titration was carried out. Two singlets at $\delta 8.5 \mathrm{ppm}$ for two urea protons were shifted downfield up to $\delta 9.2 \mathrm{ppm}$ when two equivalents of iodide ions added, but when ligand 1 was complexed with sodium ion, downfield shift was increased into $\delta 9.7 \mathrm{ppm}$ when when two equivalents of iodide ions added. Obviously the positive cooperative binding of iodide ions with ligand $\mathbf{1}$ in the presence of sodium was observed.

\section{Summary}

Two new nitrophenyl urea derivatives 1 and 2 were synthesized by the simple reaction of 4'aminobenzo-15crown-5 ether and 4-nitrophenyl isothiocyanate and 4-nitrophenyl isotcyanate. Ligand 1 bound with sodium cations and iodide anions sumultaneously with positive cooperativity. A distinct color change was observed when ligand 1 was treated with anions. Binding properties for ligand 2 was investigated. but a weak positive cooperative binding was observed

\section{Experimental}

Benzo-15-crown-5 nitrothiourea (1). To a solution $0.1 \mathrm{~g}$ $(0.35 \mathrm{mmol})$ of $4^{\prime}$-aminobenzo- 15 -crown- 5 ether in $10 \mathrm{~mL}$
THF was added with $0.06 \mathrm{~g}(0.35 \mathrm{mmol})$ of 4-nitrophenyl isothiocyanate and the reaction misture was stirred for 1 hour under the nitrogen atmosphere. The precipitate was occurred in reaction mixture. The reaction mixture was cooled and filtered to give $0.12 \mathrm{~g}(74 \%)$ of 1 : ${ }^{1} \mathrm{H}$ NMR (CD,CN) $\delta 8.50,8.45$ (two s, 2H. NH). 8.18 and 7.79 (a pair of d. $\left.4 \mathrm{H}, \mathrm{O}_{2} \mathrm{NArH} . J=8.5 \mathrm{~Hz}\right), 6.95(\mathrm{~m} .3 \mathrm{H}, \mathrm{ArH}$ with crown unit), 4.07. 3.79 and 3.63 (three $\mathrm{m}$. $16 \mathrm{H}$. $-\mathrm{OCH}_{2}-$ ).

Benzo-15-crown-5 nitrourea (2). To a solution $0.1 \mathrm{~g}$ $(0.35 \mathrm{mmol})$ of 4 '-aminobenzo-15-crown-5 ether in $10 \mathrm{~mL}$ THF was added with $0.057 \mathrm{~g}(0.35 \mathrm{mmol})$ of 4-nitrophenyl isocyanate and the reaction misture was stirred for 6 hour under the nitrogen atmosphere. After removing the solvent, the residue was washed in $\mathrm{MeOH}$ and filtered to give $0.11 \mathrm{~g}$ (71\%) of 2: ${ }^{1} \mathrm{H} \mathrm{NMR}\left(\mathrm{CD}_{3} \mathrm{CN}\right) \delta 7.83,7.33$ (two s. $2 \mathrm{H}, \mathrm{NH}$ ), 8.15 and 7.65 (a pair of d, $\left.4 \mathrm{H} . \mathrm{O}_{2} \mathrm{NArH} . J=8.5 \mathrm{~Hz}\right) .7 .15$ (d, 1H. ArH with crown unit). 6.88 (m. $2 \mathrm{H}$, ArH with crown unit), 4.05 .3 .79 and 3.63 (tluree m. $16 \mathrm{H}$. $-\mathrm{OCH}_{2}-$ ).

Acknowledgments. This work was supported by Ministry of Education of Korea (BK2l project). NMR spectra were taken at the Korea Basic Science Institute. Kwangiu. Korea This work was supported by the Regional Teclunology Innovation Program of the Ministry of Commerce. Industry and Energy (grant No. RTI 04-03-03).

\section{References}

1. Massinno. C.: Maija. N.: Antonella. D. C.: Luigi. M.: Kari. R. J. Ant Chent Soc. 2004. 126. 16507

2. Guo. D. S.: Liu. Z. P.: Ma. J. P.: Huang. R. Q. Tetrohedron Lett. 2007. 18,1221 .

3. Kang. S. O. Nam, K. C. Bull. Kowan Chem. Soc. 2002, 23. 640 .

4. Tumcharern. G.: Tuntulanii. I.: Coles. S. T.: Hursthouse. M. B.: Kilbum. T. D. Org. Lett. 2003. 5.4971.

5. Reetz. M. I.: Tohnson. B. M: Harms. K. Tetwhedron Lett. 1994. 35. 2525 .

6. Sessler. J. L.; Cyr. M. J.: Lynch. V: MoGhee. E.: [bers. J. A. J. Am. Chem. Soc $1990,112,2810$.

7. Gale. P. A Coord Chent Rev 2003. $2+0.1$.

8. Jose. D. A.: Kumar. D. K.: Ganguly. B.: Das. A. Org. Lett. 2004. 6. 3445 .

9. Thiagarajan, V: Ramamurthy, P: Thirumala, D.: Ramakrishnan. V. T. Org. Lett. $2005,7.657$.

10. (a) Suksai. C.: Tuntulani, T. Chem. Soc. Rev 2003, 32. 192. (b) Kimn. H. J.: Kimn. S. H.: Quang. T. D.: Kim. .. H.: Suh. I. H.: Kim. J. S. Bull. Korean Chem. Soc. 2007. 28.811.

11. (a) Boiocchi. M.: Boca. L. D.: Gomez. D. E.: Habbrizzi. L.: Licchellı, M.: Monzanı, E. J. Am. Chem. Soc. 2004. 126. 16507. (b) Boiocehı, M; Boca, L. D; Gomez, D. E.: Fabbrizzı, L: Licchelli, M.: Monzani. E. Chem. Eur J. 2005, 11. 3097

12. Gomez. D. E.: Habbrizzi. L.: Licehelli. M. J. Org. Chem. 2005. 70. 5717.

13. Kiml. K. S.: Kang. S. Y.: Yeo. H. M.: Nam. K. C. Bull. Korean Chem. Soc. 2007, 28(10). 1815

14. (a) Association constants were obtaned using the computer program ENGFITTER available from Elsevier-BIOSOFT. 68 Hills Road. Cambridge CB2 lLA. U.K. (b) Connors. K. A. Binding Constants: Wiley: New York. 1987 